\title{
Efektifitas Tablet Effervescent Ekstrak Kulit Manggis (Garcinia mangostana L) sebagai Pembersih Gigi Tiruan Resin Akrilik terhadap Candida albicans
}

\author{
(The Effectivity of Mangosteen Peel Extract (Garcinia mangostana) Effervescent Tablets as an Acrylic \\ Resin Denture Cleanser to Candida albicans)
}

\author{
Jovanna Andhara Arieputri ${ }^{1}$, Dewi Kristiana ${ }^{2}$, R Rahardyan Parnaadji ${ }^{3}$ \\ 1 Fakultas Kedokteran Gigi, Universitas Jember \\ 2 Departemen Prostodonsia Fakultas Kedokteran Gigi Universitas Jember \\ 3 Departemen Prostodonsia Fakultas Kedokteran Gigi Universitas Jember
}

\begin{abstract}
Abstrak
Denture stomatitis adalah inflamasi pada mukosa mulut yang berkontak dengan basis gigi tiruan yang disebabkan oleh jamur Candida albicans. Denture stomatitis dapat dicegah dengan melakukan pembersihan gigi tiruan baik secara mekanik maupun secara kimiawi. Ekstrak kulit manggis telah terbukti dapat menghambat pertumbuhan C. albicans, namun efektifitasnya sebagai bahan pembersih gigi tiruan perlu ditingkatkan. Salah satu cara untuk meningkatkan efektifitas adalah dengan mengkombinasikan pembersihan secara kimiawi dan mechanical cleansing melalui tablet effervescent. Tujuan penelitian adalah untuk mengetahui efektifitas - tablet effervescent ekstrak kulit manggis sebagai pembersih gigi tiruan akrilik terhadap C. albicans. Sebelumnya dilakukan pembuatan tablet effervescent ekstrak kulit manggis konsentrasi $30 \%$ dan $60 \%$. Sampel resin akrilik heat cured diinkubasi ke dalam tabung reaksi yang telah berisi suspensi $\mathrm{C}$. Albicans selama 24 jam pada suhu $37^{\circ} \mathrm{C}$. Selanjutnya sampel direndam dalam tablet effervescent ekstrak kulit manggis selama 15 dan 30 menit. Dilakukan penghitungan jumlah sel C. Albicans menggunakan spektrofotometer. Hasil penelitian menunjukkan erdapat penurunan jumlah sel C. albicans yang menempel pada permukaan plat setelah direndam ke dalam tablet effervescent ekstrak kulit manggis $30 \%$ dan $60 \%$ secara signifikan $(p<0,05)$. Tablet effervescent ekstrak kulit manggis $60 \%$ lebih banyak menurunkan jumlah sel $\mathrm{C}$. albicans. Lama perendaman tidak menunjukkan hasil yang berbeda secara signifikan $(p>0,05)$. Tablet effervescent ekstrak kulit manggis konsentrasi $60 \%$ yang direndam selama 15 menit paling efektif sebagai pembersih gigi tiruan resin akrilik terhadap C. albicans.
\end{abstract}

Kata Kunci: Denture stomatitis, Candida albicans, ekstrak kulit manggis, tablet effervescent

\begin{abstract}
Denture stomatitis is inflammation of the oral mucosa in contact with the denture base caused by the fungus Candida albicans. Denture stomatitis can be prevented by cleaning the dentures either mechanically or chemically. Mangosteen peel extract has been shown to inhibit the growth of $C$. albicans, but its effectiveness as a denture cleaning agent needs to be improved. One way to increase effectiveness is by combining chemical cleansing and mechanical cleansing through effervescent tablets. The aim of the study was to determine the effectiveness of mangosteen peel extract effervescent tablets as an acrylic denture cleaner against C. albicans. Previously, the effervescent tablets of mangosteen peel extract were made with concentrations of $30 \%$ and $60 \%$. Heat cured acrylic resin samples were incubated into a test tube containing $C$. albicans suspension for 24 hours at 37 oC. Furthermore, the samples were immersed in effervescent tablets of mangosteen peel extract for 15 and 30 minutes. The number of $C$. albicans cells was counted using a spectrophotometer. The results showed that there was a significant reduction in the number of $C$. albicans cells attached to the plate surface after immersion in $30 \%$ and $60 \%$ effervescent tablets of mangosteen peel extract $(p<0.05)$. Mangosteen peel extract effervescent tablets $60 \%$ more decreased the number of $C$. albicans cells. The duration of immersion did not show significantly different results $(p>0.05)$. Effervescent tablets of $60 \%$ concentration of mangosteen peel extract soaked for 15 minutes were the most effective as an acrylic resin denture cleaner against $\mathrm{C}$. albicans.
\end{abstract}

Keywords: Candida albicans, denture stomatitis, effervescent tablets, mangosteen peel extract $\begin{aligned} \text { Korespondensi (Correspondence) : } & \text { Bagian Prostodonsia Fakultas Kedokteran Gigi Universitas Jember. J. } \\ & \text { Kalimantan 37, Jember. } 68121 .\end{aligned}$

Denture stomatitis adalah inflamasi pada mukosa mulut yang berkontak dengan basis gigi tiruan sebagian lepasan atau gigi tiruan lengkap. Denture stomatitis dapat disebabkan salah satunya yaitu jamur Candida albicans. Pertumbuhan jamur C. albicans ditemukan sebanyak $70 \%$ penderita denture stomatitis. ${ }^{1}$ Denture Stomatitis dapat diturunkan prevalensinya dengan cara membersihkan gigi tiruan untuk mencegah atau mengurangi C. albicans. ${ }^{2}$

Bahan-bahan pembersih gigi tiruan yang berasal dari bahan tradisional dari tanaman telah banyak digunakan salah satunya yaitu ekstrak kulit manggis yang diketahui mampu berfungsi sebagai fungistatik sesuai dengan penelitian yang telah dilakukan oleh Aprilliasari (2014), menunjukkan ekstrak kulit manggis dengan konsentrasi $30 \%$ dan $60 \%$ mempunyai fungsi untuk menghambat pertumbuhan $C$. albicans. Ekstrak kulit manggis dengan kosentrasi $60 \%$ didapatkan lebih efektif dalam menghambat pertumbuhan $C$. albicans dibandingkan dengan ekstrak kulit manggis dengan konsentrasi 30\%.3 Kulit buah manggis mempunyai kandungan aktif didalamnya sehingga mempunyai fungsi untuk 
menghambat pertumbuhan C. albicans yaitu senyawa golongan alkaloid, triterpenoid, saponin, flavonoid, tanin dan polifenol. ${ }^{4}$

Denture stomatitis dapat dicegah dengan melakukan pembersihan atau penyikatan gigi tiruan secara mekanik dan secara kimiawi dengan bahan pembersih gigi tiruan yang mengandung desinfektan. Bahan pembersih gigi tiruan dapat berbentuk pasta, tablet dan cairan. ${ }^{5}$ Pemakai gigi tiruan biasanya menggunakan cara kimiawi karena pembersihan secara mekanis kurang efektif pembersihannya yang hanya menghilangkan sisa-sisa makanan dan jika dilakukan secara berulang dapat menyebabkan keausan dan goresan pada permukaannya. ${ }^{6}$

Resin akrilik tipe heat cured merupakan bahan basis gigi tiruan yang sering digunakan.? Gigi tiruan resin akrilik heat cured dalam pemeliharaannya terdiri dari frekuensi, waktu, dan cara pembersihannya agar dapat mengindikasikan pemeliharaan kebersihan yang benar. 8 Penulis menginginkan dalam pembersihan gigi tiruan agar tidak memerlukan waktu yang lama dalam proses pembersihan dan keefektifitasnya meningkat. Ekstrak kulit manggis dalam penggunaannya masih perlu ditingkatkan keefektifitasnya salah satu caranya dengan mengkombinasikan antara pembersihan secara kimiawi dengan mechanical cleansing dengan cara pembuatan tablet effervescent ekstrak kulit manggis.

C. albicans mengalami perlekatan dan kolonisasi pada basis gigi tiruan melalui interaksi non spesifik dan interaksi spesifik. Interaksi non spesifik atau disebut juga interaksi hidrofobik disebabkan oleh adanya sifat dari C. albicans yang relatif hidrofilik dan permukaan basis gigi tiruan bersifat hidrofobik. Ikatan spesifik sendiri disebabkan karena adanya ikatan yang berafinitas tinggi yang melibatkan rantai sisi hidrat arang glikoprotein saliva sebagai reseptor dengan mannoprotein C. albicans sebagai adhesion. ${ }^{9}$ Ikatan tersebut dapat dirusak dengan memerlukan kekuatan dari $\mathrm{CO}_{2}$ dari hasil reaksi antara bahan pembersih gigi tiruan yaitu tablet effervescent dengan air. Tablet effervescent jika dilarutkan ke dalam air akan terjadi reaksi kimia antara asam dan natrium bikarbonat sehingga terbentuk garam natrium dari asam dan menghasilkan gas karbondioksida serta air. ${ }^{10}$ Gas tersebut akan bertindak sebagai mechanical cleansing yang akan melepaskan interaksi antara C. albicans dengan permukaan resin akrilik."11

Berdasarkan uraian diatas, maka penulis ingin meneliti lebih lanjut mengenai efek tablet effervescent ekstrak kulit manggis (Garcinia mangostana L) sebagai pembersih gigi tiruan resin akrilik dengan masing-masing konsentrasi dan lama perendaman yang berbeda berdasarkan penelitian Aprilliasari (2014) yaitu $30 \%$ dan $60 \%$ dengan waktu perendaman 15 dan 30 menit. Pencampuran antara ekstrak kulit manggis dengan tablet effervescent diharapkan dapat mempersingkat waktu serta dapat meningkatkan keefektifan dalam menghambat pertumbuhan $C$. albicans. Pencampuran tersebut juga diharapkan untuk mempermudah pengguna dalam melakukan permbersihan gigi tiruan karena hanya direndam dalam waktu singkat sudah efektif dalam pembersihannya.

\section{METODE PENELITIAN}

Jenis penelitian yang digunakan adalah experimental laboratory dengan rancangan penelitian yaitu the post test with control group design. Sampel yang digunakan sebanyak 25 sampel yang dibagi menjadi 5 kelompok yaitu kelompok kontrol positif dan kelompok perlakuan. Kelompok perlakuan yaitu tablet effervescent ekstrak kulit manggis dengan perbedaan konsentrasi $30 \%$ dan $60 \%$ serta lama perendaman selama 15 dan 30 menit.

Cara pembuatan ekstrak kulit manggis yaitu buah manggis dikupas diambil kulit manggisnya. Kulit manggis diekstrak menggunakan blender dengan perbandingan antara kulit manggis dengan air adalah 100 gram kulit manggis bagian dalam ditambahkan dengan $800 \mathrm{ml}$ air. Menyaring dengan ayakan mesh No. 100 sambil diaduk. Menambahkan maltodekstrin sebesar $30 \%$ lalu dikeringkan dengan menggunakan spray dryer sehingga diperoleh ekstrak kulit manggis kering.

Cara pembuatan tablet effervescent dilakukan dengan metode kempa langsung. Formulasi yang akan dibuat terdiri dari kandungan campuran asam basa dengan perbandingan untuk asam sitrat, asam tartar dan natrium bikarbonat $(1: 2: 3,4)$. Ekstrak kulit manggis dicampur dengan campuran asam sitrat, asam tartat dan sebagian PVP. Digerus hingga halus. Komponen ini disebut komponen asam. Natrium bikarbonat dicampur dengan campuran laktosa dan maltosa lalu digerus hingga halus. Komponen ini disebut dengan komponen basa. Kedua komponen dicampurkan menjadi satu, lalu ditimbang seberat tablet yang diinginkan lalu dicetak ke dalam mesin tablet.

Sampel resin akrilik heat cured yang

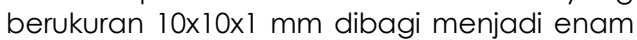
kelompok perlakuan. Merendam sampel resin akrilik ke dalam akuades steril selama $2 \times 24$ jam. Mensterilkan sampel resin akrilik menggunakan autoclave $121^{\circ} \mathrm{C}$ selama 15 menit kemudian merendam ke dalam saliva steril selama 1 jam lalu membilas dengan PBS sebanyak dua kali. Memasukkan sampel resin akrilik ke dalam tabung reaksi yang telah berisi suspensi C. Albicans. Meninkubasi selama 24 jam pada suhu $37^{\circ} \mathrm{C}$. Merendam sampel resin akrilik sesuai dengan kelompok perlakuan yaitu kelompok kontrol dan kelompok tablet effervescent ekstrak kulit manggis dengan konsentrasi direndam selama 15 dan 30 menit kemudian dibilas dengan PBS sebanyak dua kali. Memasukkan 
sampel resin akrilik ke dalam $10 \mathrm{ml}$ saboraud broth, kemudian di vibrasi dengan vortex pada semua tabung reaksi selama 30 detik. Menghitung jumlah sel C. Albicans dengan menggunakan spektrofotometer. dari masingmasing kelompok.

\section{HASIL}

Hasil data tersebut didapatkan rata-rata jumlah sel C. albicans setelah dikonversikan dengan rumus dapat dilihat pada tabel 1 . Hasil uji normalitas dengan uji Shapiro-Wilk menunjukkan bahwa nilai probabilitas lebih besar dari $0,05 \quad(p>0,05)$. Hasil data yang didapatkan berdistribusi normal. Hasil uji homogenitas dengan uji Levene-Statistic menunjukkan bahwa nilai probabilitas lebih besar dari $0,05(p>0,05)$. Hasil ini berarti data tersebut memiliki variasi yang homogen.

Tabel 1. Jumlah sel C. albicans pada Lempeng Resin Akrilik $(n=5)$

\begin{tabular}{cc}
\hline Perlakuan & Jumlah sel $\left(\times 10^{8}\right)$ \\
\hline K+ & $34,6 \pm 0,11$ \\
$30 \% 15$ menit & $25 \pm 0,2$ \\
$30 \% 30$ menit & $24,8 \pm 0,13$ \\
$60 \% 15$ menit & $23,2 \pm 0,23$ \\
$60 \% 30$ menit & $22,4 \pm 0,14$ \\
\hline
\end{tabular}

Hasil analisis statistik dengan menggunakan uji Two Way Anova pada Tabel 2. didapatkan nilai pada variabel Konsentrasi (Kontrol positif dan Tablet effervescent ekstrak kulit manggis konsentrasi $30 \%$ dengan $60 \%$ ) didapatkan $p=0.000 \quad(p<0,05)$. Hasil uji menunjukkan bahwa diantara masing-masing konsentrasi terdapat perbedaan yang bermakna yang artinya terdapat perbedaan jumlah sel C. albicans pada tiap konsentrasi. Perbedaan antar konsentrasi tersebut dapat diketahui dengan menggunakan uji post $\mathrm{Hoc}$ Two way Anova, yaitu dengan menggunakan uji Least Significance Difference (LSD). Hasil uji pada variabel lama perendaman didapatkan $p=0,054(p>0,05)$ yang menunjukkan bahwa antara masing-masing lama perendaman tidak terdapat perbedaan yang bermakna.

Tabel 2. Ringkasan Hasil Uji Two Way Anova

\begin{tabular}{ll}
\hline Kelompok & Sig. \\
\hline Konsentrasi & .000 \\
Lama Perendaman & .054 \\
\hline
\end{tabular}

Tabel 3. Ringkasan Hasil Uji LSD

\begin{tabular}{llll}
\hline & Kontrol & $30 \%$ & $60 \%$ \\
\hline Kontrol & - &, 000 &, 000 \\
$30 \%$ &, 000 & - &, 000 \\
$60 \%$ &, 000 &, 000 & - \\
\hline
\end{tabular}

Hasil uji post-hoc LSD pada Tabel 3 menunjukkan terdapat perbedaan yang bermakna pada semua konsentrasi untuk variabel konsentrasi. Hal ini dapat dibuktikan dengan nilai signifikansi setiap kelompok kurang dari $0,05(p<0,05)$ yang menunjukkan pada setiap masing-masing kelompok perlakuan mempunyai perbedaan yang bermakna.

\section{PEMBAHASAN}

Hasil rata-rata jumlah sel C. albicans setelah dikonversikan ke dalam rumus pada Tabel 1. menunjukkan terdapat perbedaan antara masing-masing kelompok konsentrasi. Jumlah sel C. albicans yang berbeda ini menunjukkan banyaknya jumlah $\mathrm{C}$. albicans yang terlepas dari plat akrilik setelah dilakukan vibrasi pada vortex. Jumlah sel C. albicans yang didapatkan diasumsikan sebagai jumlah C. albicans yang masih melekat atau menempel pada permukaan plat setelah direndam ke dalam tablet effervescent ekstrak kulit manggis dengan perbedaan konsentrasi yaitu $30 \%$ dan $60 \%$ dengan lama perendaman yang berbeda yaitu selama 15 dan 30 menit. C. albicans tersebut dilakukan perhitungan kekeruhan dengan menggunakan spektrofotometer.

Tabel 1. menunjukkan bahwa perendaman dalam tablet effervescent ekstrak kulit manggis dengan konsentrasi $60 \%$ mempunyai efektivitas yang lebih baik dibandingkan dengan perendaman dalam perlakuan kontrol tablet effervescent dent a clear dan tablet effervescent ekstrak kulit manggis dengan konsentrasi $30 \%$. Konsentrasi yang mengalami peningkatan tersebut dapat menjadi penyebab perbedaan keefektifitas dari perendaman bersebut. Hal ini sesuai penelitian Fakhrurrazi (2016) yaitu konsentrasi asam jawa yang digunakan semakin tinggi maka semakin rendah pertumbuhan $C$. albicans pada lempeng akrilik tipe heat cured. ${ }^{11}$

Tablet effervescent jika dimasukkan ke dalam air, mulailah terjadi reaksi kimia antara asam dan natrium bikarbonat sehingga terbentuk garam natrium dari asam dan menghasilkan gas atau gelembung gas karbondioksida serta air.10 Menurut Parnaadji (2003), natrium bikarbonat mempunyai aktivitas sebagai pembersih gigi tiruan karena natrium bikarbonat merupakan suatu garam yang terbentuk dari asam lemah dengan basa kuat yang jika dilarutkan ke dalam air akan menghasilkan larutan yang bersifat basa. Larutan yang bersifat basa ini dapat melawan C. albicans yang bersifat acidophil. Natrium bikarbonat dalam proses pelepasan koloni $C$. albicans juga dipengaruhi oleh adanya gelembung gas karbondioksida yang akan bertindak sebagai mechanical cleansing. Gelembung gas tersebut akan medesak dan mengakibatkan ikatan hidrofobik antara $C$. albicans dengan basis gigi tiruan dan ikatan mannoprotein C. albicans akan terputus sehingga C. albicans dapat terlepas dari permukaan resin akrilik. ${ }^{9}$ Reaksi kimia tablet effervescent menurut Ansel (2005) sebagai berikut: 12

$\mathrm{H}_{3} \mathrm{C}_{6} \mathrm{H}_{5} \mathrm{O}_{7} \cdot \mathrm{H}_{2} \mathrm{O}+3 \mathrm{NaHCO}_{3} \rightarrow \mathrm{N}_{3} \mathrm{C}_{6} \mathrm{H}_{5} \mathrm{O}_{7}+4 \mathrm{H}_{2} \mathrm{O}+3 \mathrm{CO}_{2}$ $\mathrm{H}_{2} \mathrm{C}_{4} \mathrm{H}_{4} \mathrm{O}_{6}+2 \mathrm{NaHCO}_{3} \rightarrow \mathrm{Na}_{2} \mathrm{C}_{4} \mathrm{H}_{4} \mathrm{O}_{6}+2 \mathrm{H}_{2} \mathrm{O}+2 \mathrm{CO}_{2}$ 
Xanthon merupakan salah satu kandungan utama dari kulit buah manggis yang mempunyai sifat antifungi dan merupakan golongan polifenol. Alphamangostin merupakan salah satu turunan dari xanthon. Alpha mangostin mempunyai sifat antifungi salah satunya pada C. albicans dengan mengubah struktur dan integritas permukaan sel serta menghambat adhesi pada sel C. albicans. Alpha-mangostin juga dapat menganggu perubahan pada permukaan sel yang akan menyebabkan pergeseran energi bebas interaksi antara sel dengan permukaan gigi tiruan. ${ }^{13}$ Selain itu, alpha-mangostin juga memiliki potensi dalam pengobatan kandidiasis mulut yang menunjukkan bahwa daya hambat $C$. albicans pada alfa-mangostin lebih baik dari clotrimazole dan nystatin karena dapat bereaksi dengan menyerang struktur dan fungsi pada sel jamur dan komponen pada lipid dengan membran yang terpenting pada kehidupan sel jamur. ${ }^{14}$

Senyawa flavonoid dapat bekerja dengan denaturasi protein untuk meningkatkan permeabilitas membran sel. Denaturasi protein tersebut menyebabkan gangguan dalam pembentukan sel yang dapat merubah komposisi komponen protein. Membran sel akan terganggu yang mengakibatkan kerusakan sel jamur yang akhirnya menyebabkan kematian sel.15 Senyawa flavonoid juga dapat membentuk senyawa kompleks yang akan merusak membran sel dari C. albicans. ${ }^{16}$

Potensi daya hambat yang dihasilkan oleh ekstrak kulit buah manggis terhadap pertumbuhan $C$. albicans pada penelitian ini disebabkan oleh zat-zat aktif yang terkandung didalam kulit buah manggis salah satunya saponin yang juga berfungsi sebagai antifungi. Hal ini diperkuat oleh penelitian yang dilakukan oleh Soetan (2006) bahwa saponin dan tanin dalam batang kol mampu menghambat pertumbuhan C. albicans. ${ }^{12}$ Hal ini dikarenakan saponin bekerja dengan cara berikatan dengan membran sterol pada dinding sel jamur yang menyebabkan pembentukan pori sehingga integritas membran sel jamur akan hilang. Senyawa tanin memiliki keefektifan dalam menghambat pertumbuhan $C$. albicans dengan cara menyempitkan dan mengendapkan protein yang ada pada membran sel jamur. ${ }^{13}$

Penelitian ini bertujuan untuk mendapatkan konsentrasi dan lama perendaman yang singkat dan efektif dalam membersihkan basis gigi tiruan. Hasil penelitian pada Tabel 2 pada variabel lama perendaman (selama 15 dan 30 menit) menunjukkan nilai signifikasi yang didapatkan yaitu $p=0,054$ dimana nilai tersebut menunjukkan tidak terdapat perbedaan yang bermakna dari masing-masing lama perendaman. Lama perendaman selama 15 menit maupun 30 menit menunjukkan tidak terdapat perbedaan yang bermakna $(p>0,05)$. Hasil tersebut dapat disimpulkan bahwa lama perendaman yang dilakukan selama 15 maupun 30 menit tidak berpengaruh secara signifikan dalam menghambat pertumbuhan $C$. albicans yang artinya lama perendalam 15 maupun 30 menit mempunyai tingkat keefektifan yang sama dalam menghambat pertumbuhan $C$. albicans.

Berdasarkan hasil penelitian yang telah dilakukan, dapat disimpulkan bahwa Konsentrasi dan waktu yang paling efektif sebagai pembersih gigi tiruan resin akrilik terhadap C. albicans adalah tablet effervescent ekstrak kulit manggis dengan konsentrasi $60 \%$ yang direndam selama 15 menit.

\section{DAFTAR PUSTAKA}

1. Herawati E, Novani D. Penatalaksanaan Kasus Denture Stomatitis. Bandung: J Ked Gi Unpad Unpad. 2017

2. Lahama, L., Wowor, V.N.S. \& Amelia, O. Angka Kejadian Stomatitis yang Diduga sebagai Denture Stomatitis pada Pengguna Gigi Tiruan di Kelurahan Batu Kota Manado. Pharmacon. 2015; 4(4): 72.

3. Aprilliasari D. Pengaruh Konsentrasi dan Lama Perendaman Ekstrak Kulit Manggis (Garcinia mangostana L) terhadap Pertumbuhan Candida albicans pada Plat Gigi Tiruan Resin Akrilik Heat Cured. Yogyakarta: Universitas Muhammadiyah Yogyakarta Universitas Muhammadiyah Yogyakarta. 2014.

4. Dewi Astuti, KW, Warditiani, NK. Skrining Fitokimia Ekstrak Etanol 95\% Kulit Buah Manggis (Garcinia mangostana L.). Jurnal. Bali: Universitas Udayana. 2013.

5. Dharmautama M., Machmud E, Maruapey AM. Pasta Pembersih Gigitiruan Bunga Rosella (Hibiscus sabdariffa L.) Menghambat Pembentukan Plak pada Basis Akrilik Gigitiruan. Jurnal Makassar: PPDGS Prostodonsia Universitas Hasanuddin. 2013.

6. Atmaja WD, Kulit Buah Kakao (Theobroma kakao L) sebagai Bahan Pembersih Gigi Tiruan dan Mencegah Perlekatan Candida albicanspada Basis Plat Akrilik. Stomatognatic (J. K. G Unej), 12(2): 46-50.

7. Craig GR, Powers JM. Restorative Dental Materials. $11^{\text {th }}$ ed. Philadelphia: CV Mosby. 2002

8. Lengkong PEO., Pangemanan, DHC, Mariati NW. Gambaran Perilaku dan Cara Merawat Gigi Tiruan Sebagian 
Lepasan pada Lansia di Panti Werda Minahasa Induk. Jurnal e-Gigi, 2015; 3(1).

9. Parnaadji R. Bahan-bahan Pemberisih Gigitiruan untuk Mencegah Denture Stomatitis. Stomatognatic, 2003; 1(1): 126.

10. Setiana, IH, Kusuma, ASW. Review Jurnal: Formulasi Granul Effervescent dari Berbagai Tumbuhan. Farmaka, 2018; 16(3): 100-5.

11. Fakhrurrazi HRF, Keumala CN. Pengaruh Daun Asam Jawa (Tamarindus Indica Linn) terhadap Pertumbuhan Candida albicans. Journal of Syiah Kuala Dentistry Society, 2016; 1 (1): 29-34.

12. Ansel HC. Pengantar bentuk sediaan farmasi. edisi IV ed. Jakarta: UI Press. 2005.

13. Kaomongkolgit R, Jamdee K. Inhibitory Effect of Alpha-Mangostin on Adhesion of Candida albicans to Denture Acrylic. The Open Dentistry Journal, 2015: 388-92.

14. Kaomongkolgit $\mathrm{R}$, Jamdee $\mathrm{K}$, Chaisomboon N. Antifungal Activity of
Alpha-mangostin Against Candida albicans. Journal of Oral Science. 2009; $51(3)$, : 401-6.

15. Azaalea MR., Ashrin MN, Widaningsih. Efektifitas Ekstrak Daun Mangrove Avicennia Alba terhadap Penurunan Jumlah Koloni Candida albicans pada Basis Gigi Tiruan Akrilik. Denta Jurnal Kedokteran Gigi, 2014; 8 (2): 19-26.

16. Alveno A, Ashrin MN, Damaiyanti DW. Pengaruh Effervescent Ekstrak Kulit Nanas dalam Menghambat Pertumbuhan Candida albicans pada Resin Akrilik Heat Cured. Denta Jurnal Kedokteran Gigi. 2016; 10(2): 135-41.

17. Soetan KO., Oyekunle MA. Aiyelaagbe OO., Fafunso MA. Evaluation og the Antimicrobial Activity of Saponins Extract of Sorghum Bicolor L. Moench. African Journal of Biotechnology, 2006; 5(23)

18. Sianturi AK, Wowor VNS, Suling PL. Uji Daya Hambat Ekstrak Meniran terhadap Pertumbuhan Candida albicans yang Diisolasi dari Plat Gigi Tiruan Lepasan Akrilik. Pharmacon, 2016; 5(2). 